\title{
Technical note \\ The performance of an infiltration gallery used as a simple water treatment option for a small rural community - Goviefe-Agodome in the Volta Region, Ghana
}

\author{
EB Asare ${ }^{1}$ and EK Bosque-Hamilton ${ }^{2 *}$ \\ ${ }^{1}$ Groundwater Division, CSIR - Water Research Institute, PO Box M32 Accra, Ghana \\ ${ }^{2}$ Environmental Chemistry Division, CSIR - Water Research Institute, PO Box M32 Accra, Ghana
}

\begin{abstract}
An infiltration gallery was successfully installed at Goviefe-Agodome in Ghana after unsuccessful attempts at obtaining groundwater for the community. Results obtained from laboratory analysis carried out on water samples taken from the infiltration gallery showed that most of the physico-chemical characteristics of the filtered water were within the WHO (1993) guidelines and were higher than the raw water parameters. Leaching of lime and other constituents of cement used in the construction work accounted for the increase in ionic content. The bacteriological quality of the filtered water was acceptable. The pond needed protection from human contact and a simple iron removal system was installed to remove excess iron in the filtered water.
\end{abstract}

\section{Introduction}

The provision of reliable and safe water for the majority of the population living in rural areas is a major challenge for the government of Ghana (Andani, 1996). It is for this reason that the government and several NGOs have initiated many water projects for rural communities. In the Volta Region many schemes utilising surface or groundwater sources have been implemented to provide water to about $1.7 \mathrm{~m}$. people. In spite of the wide water supply coverage in the region, many communities still have no access to a reliable supply of potable water because of the seasonal drying up of wells and ephemeral streams. One such community is GoviefeAgodome (N6 42.53', E0²0.14'), which has no safe and reliable source of potable water because previous attempts to harness groundwater resources have been unsuccessful. The only source of water in the community is a pond that was created by making an earth dam across a dry stream channel. The source is considered highly unsafe for potable uses because of animal and human contact with the pond water. This situation necessitated the provision of a simple water treatment facility to improve potability. A simple infiltration gallery was therefore built to serve that purpose. This technical note highlights the performance of the infiltration gallery.

\section{Objectives}

The objectives of the study were to:

- Improve the potability of the water source for Goviefe-Agodome

- Evaluate the performance of the installed infiltration gallery.

\section{Material and methods}

\section{Description of site}

Goviefe-Agodome is a farming community with a population of about 2500 people mostly engaged in food crop cultivation at

* To whom all correspondence should be addressed.

푱+233 21-779515; fax: +23321-777170; e-mail: ekbosque@yahoo.com Received 12 February 2003; accepted in revised form 15 December 2003. subsistence level and agro-forestry. Goviefe is located in the Volta Region of Ghana, $60 \mathrm{~km}$ south of Hohoe, the district capital. The settlement lies $1 \mathrm{~km}$ gradient of the source of water supply, a pond. The pond is circular in shape with a diameter of about $100 \mathrm{~m}$. It is generally perennial and dries up only after long periods of drought, generally uncharacteristic of the area.

\section{Design and operation of the facility}

The inhabitants of the village constructed the facility based on the following considerations:

- Availability of raw materials

- No usage of chemicals

- No mechanical or electrical moving parts

- A system that is easy to operate and maintain and simple enough to be managed by a village community.

The facility consists of three shallow wells located in series which are 54 to $74 \mathrm{~m}$ away from the pond (Fig. 1). Two of the wells (prefilter and filter wells) are square. These were charged with filter media. Sand of effective size $0.52 \mathrm{~mm}$ and uniformity co-efficient of 2.308 was used as filter medium. The sand was readily available, easy to clean and could be used without screening. The third well (filtered water collection well) is circular with a diameter of $1.4 \mathrm{~m}$. This size was chosen to allow free movement during the construction of the well and also to create additional space for storage, since water demand is high in the mornings.

To ensure the use of locally available materials, sandcrete blocks joined together by cement-sand-water mix (mortar) were used as a lining to protect the walls of the wells. Four-inch PVC pipes were used as conduits to carry raw water from the pond through the filter system into the collection and storage well. Ordinary portland cement was used to prepare mortar for joining and cementing of the sandcrete blocks. Details of construction as well as the material schedule are described in Asare (1996). A hand-pump was mounted on the collection well to draw filtered water. Due to long retention time in the pond most of the suspended particles settle in the pond before reaching the filters. The filters can be operated for long periods before clogging takes place. For 


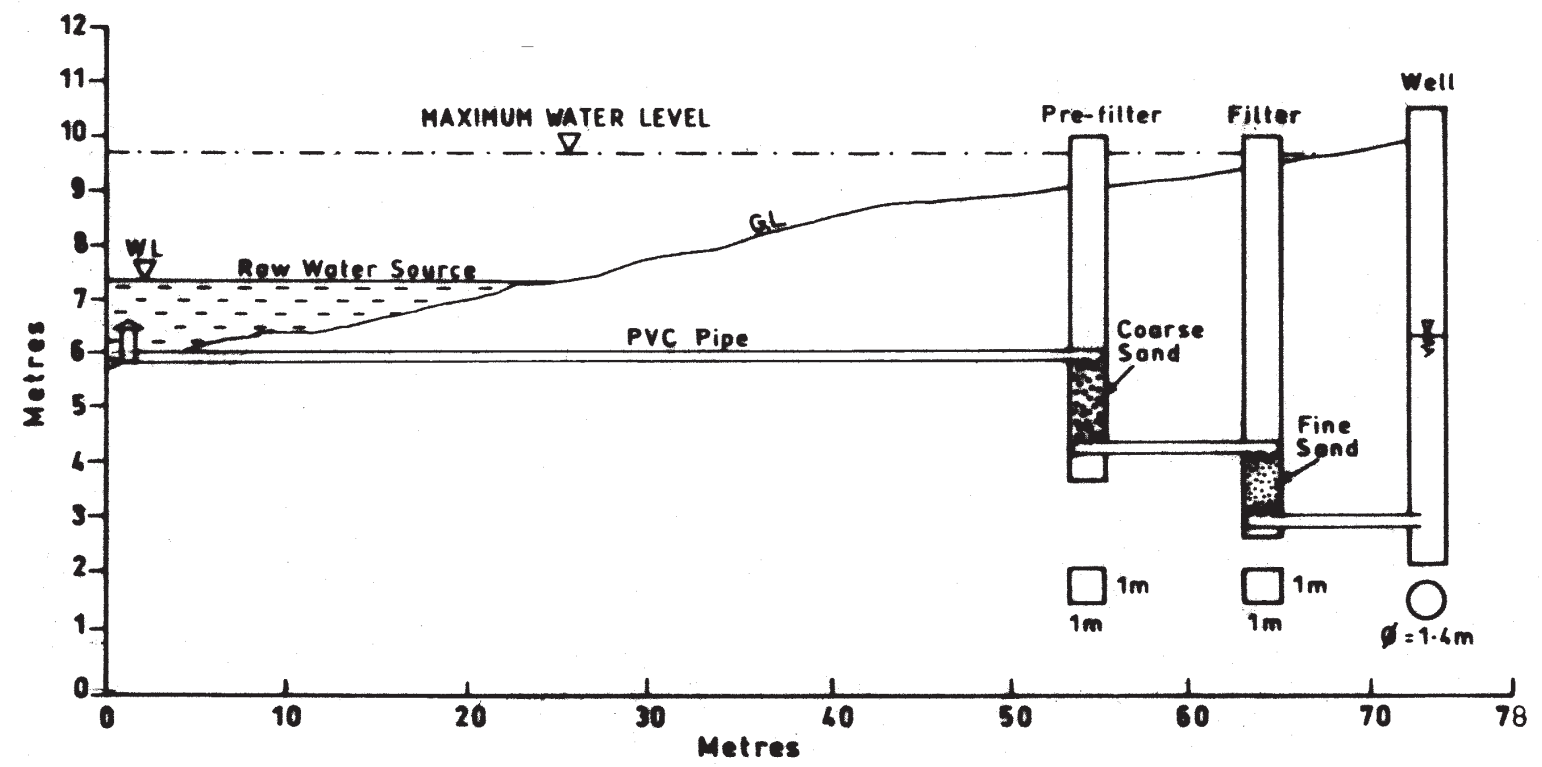

Figure 1

Infiltration gallery at Goviefe-Agodome

routine maintenance of the system, the filter media are removed and cleaned by the local inhabitants.

\section{Sample collection and water quality analyses}

Samples were collected from the pond and collection well into two well-cleaned $1 \ell$ plastic bottles every two months over a period of two years after start-up of the treatment facility. Samples were kept in an icechest at $4^{\circ} \mathrm{C}$ and transported to the Water Research Institute, Ghana for analyses within 2 to $4 \mathrm{~h}$. The water quality parameters considered in this study comprised physical parameters, nutrients, major cations and anions and bacteriological parameters like total and faecal coliforms. Conductivity, $\mathrm{pH}$ and turbidity were determined on-site immediately after collection of samples. Samples were analysed according to Standard Methods (1998). Samples for bacteriological analyses were collected in sterile $100 \mathrm{~m} \ell$ bottles, kept in an ice-chest at $4^{\circ} \mathrm{C}$ and analysed within $4 \mathrm{~h}$. Bacteriological parameters were limited to total and fecal coliforms and assessed by the membrane filtration methods as described in WHO (1987) and Standard Methods (1998).

A summary of physical and chemical results is given in Table 1.

\section{Results}

\section{Physical quality of raw and treated water}

The $\mathrm{pH}$ varied between 6.17 and 7.8 for the pond water with a mean of 6.92. The pond water is slightly acidic to neutral in nature. The
TABLE 1

Results of physical and chemical analyses of water samples from infiltration gallery

\begin{tabular}{|c|c|c|c|c|c|}
\hline & \multicolumn{2}{|c|}{$\begin{array}{l}\text { Raw water } \\
\text { samples }\end{array}$} & \multicolumn{2}{|c|}{$\begin{array}{l}\text { Filtered water } \\
\text { samples }\end{array}$} & \multirow{2}{*}{$\begin{array}{l}\text { WHO (1993) } \\
\text { Guideline } \\
\text { value }\end{array}$} \\
\hline & Mean & Range & Mean & Range & \\
\hline $\mathrm{pH}$ & 6.92 & $6.17-7.8$ & 7.36 & $6.7-8.03$ & $6.5-8.5$ \\
\hline Turbidity (NTU) & 88 & $10-185$ & 28 & $<5-86$ & 5 \\
\hline Conductivity $(\mu \mathrm{S} / \mathrm{cm})$ & 143.5 & $66.8-235$ & 369 & $115-786$ & 400 \\
\hline Alkalinity (mg/l) & 62.0 & $30-88.0$ & 147 & $22.0-276$ & - \\
\hline 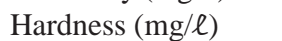 & 59 & $14.2-102$ & 141 & $54.6-296$ & 500 \\
\hline Sodium (mg/l) & 11.7 & $7.0-15.7$ & 20.4 & $9.0-43.2$ & 200 \\
\hline Potassium (mg/l) & 3.8 & $2.0-7.7$ & 6.1 & $3.2-11.2$ & 30 \\
\hline 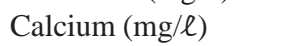 & 13.6 & $5.8-27.0$ & 29.0 & $11.2-76$ & 200 \\
\hline Magnesium (mg/l) & 5.9 & $2.1-9.5$ & 15.7 & $2.5-56$ & 150 \\
\hline 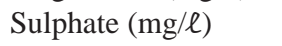 & 4.6 & $0.5-16.0$ & 10.6 & $1.4-27.0$ & 250 \\
\hline Chloride (mg/e) & 7.3 & $1.3-23.0$ & 12.0 & $2.9-57.0$ & 250 \\
\hline Nitrate (mg/l) & 3.6 & $0.5-11.0$ & 2.5 & $1.0-5.4$ & 50 \\
\hline 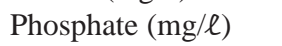 & 0.21 & $0.02-0.5$ & 0.15 & $0.01-0.29$ & - \\
\hline Silica (mg/l) & 17 & $0.6-31.7$ & 16.0 & $0.7-31.3$ & - \\
\hline Iron (mg/l) & 1.6 & $0.34-5.5$ & 4.18 & $1.07-9.0$ & 0.3 \\
\hline
\end{tabular}

filtered water had a $\mathrm{pH}$ ranging from 6.7 to 8.03 . The treatment process tended to raise the $\mathrm{pH}$ (mean $\mathrm{pH}=7.36$ ). The turbidity ranged from 10 to 185 NTU for the raw water samples with a mean of $88 \mathrm{NTU}$ and ranged between $<5$ and 86 NTU for the filtered water samples. The pond water was generally turbid ( $>100$ NTU) during the rainy seasons. Electrical conductivity is a measure of the total ionic content and ranged between 66.8 and $235 \mu \mathrm{S} / \mathrm{cm}$ for the raw water samples and between 115 and $786 \mu \mathrm{S} / \mathrm{cm}$ for the filtered water samples. The mean conductivity for treated water $(369 \mu \mathrm{S} / \mathrm{cm})$ was higher than the raw water $(143.5 \mu \mathrm{S} / \mathrm{cm})$. Water hardness (the amount of $\mathrm{CaCO}_{3}$ dissolved in water) relates to the ability of water to lather soap. Mean concentrations of total hardness (calcium and magnesium content) 
were 59 and $141 \mathrm{mg} / \ell$ for the raw water and filtered water respectively.

\section{Chemical quality of raw and treated water}

There was a general increase in ionic content as the raw water from the pond passed through the infiltration gallery. Sodium levels varied from 7.0 to $15.7 \mathrm{mg} / \ell$ for the raw water samples and from 9.0 to $43.2 \mathrm{mg} / \ell$ for the treated water. This showed a mean percentage increase of $61 \%$ in the sodium content. Similarly, mean percentage ionic content increased for potassium (raw water range: 2.0 to $7.7 \mathrm{mg} / \ell$; filtered water range: 3.2 to $11.2 \mathrm{mg} / \ell$ ), calcium (raw water range: 5.8 to $27.0 \mathrm{mg} / \ell$; filtered water range: 11.2 to $76.0 \mathrm{mg} / \ell$ ) and magnesium (raw water range: 2.1 to $9.5 \mathrm{mg} / \ell$; filtered water range: 2.5 to $56.0 \mathrm{mg} / \ell$ ) were $60 \%, 85 \%$ and $137 \%$ respectively. Chloride and sulphate concentrations also increased from the raw to filtered water. The chloride concentrations of the raw water (range: 1.3 to $23.0 \mathrm{mg} / \ell$ ) had a mean value of $7.3 \mathrm{mg} / \ell$, with filtered water (range: 2.9 to $57.0 \mathrm{mg} / \ell$ ) having a mean value of $12.0 \mathrm{mg} / \ell$. Sulphate levels (raw water range: 0.5 to $11.0 \mathrm{mg} / \ell$ ) had a mean value of $4.6 \mathrm{mg} / \ell$, with filtered water (range: 1.4 to $27.0 \mathrm{mg} / \ell$ ) having a mean value of $10.6 \mathrm{mg} / \ell$. Mean phosphate levels dropped from $0.21 \mathrm{mg} / \ell$ for the raw water (range: 0.02 to $0.5 \mathrm{mg} / \ell$ ) to 0.15 $\mathrm{mg} / \ell$ for the filtered water (range: 0.01 to $0.29 \mathrm{mg} / \ell$ ). Mean nitrate levels also dropped slightly from $3.6 \mathrm{mg} / \ell$ for the raw water (range: 0.0 to $11.0 \mathrm{mg} / \ell$ ) to $3.0 \mathrm{mg} / \ell$ for the filtered water (range: 0.0 to 5.4 $\mathrm{mg} / \ell$ ). Mean silicate levels did not change and were $17.0 \mathrm{mg} / \ell$ for the raw water (range: 0.6 to $31.7 \mathrm{mg} / \ell$ ) to $16.0 \mathrm{mg} / \ell$ for the filtered water (range: 0.7 to $31.3 \mathrm{mg} / \ell$ ). Mean total iron levels increased from $1.6 \mathrm{mg} / \ell$ for the raw water (range: 0.34 to $5.5 \mathrm{mg} / \ell$ ) to 4.18 $\mathrm{mg} / \ell$ for the filtered water (range: 1.07 to $9.0 \mathrm{mg} / \ell$ ).

\section{Bacteriological quality of raw and treated water}

The geometric means and ranges of total and faecal coliforms tested for the infiltration gallery plant are shown in Table 2. Total coliforms in the raw water recorded a geometric mean of 388 organisms/100 m $\ell$ and ranged between 180 and 4600 organisms/ $100 \mathrm{~m} \ell$. These were reduced to a geometric mean of 24 organisms/ $100 \mathrm{~m} \ell$ and a range of 6 to 80 organisms/100 $\mathrm{m} \ell$ after the installation of the infiltration gallery. Faecal coliforms had a geometric mean of 35 organisms/100m $\ell$ and ranged from 5 to 530 organisms $/ 100 \mathrm{~m} \ell$. These were reduced to a geometric mean of 3 organisms $/ 100 \mathrm{~m} \ell$ and a range of 0 to 8 organisms/100 m $\ell$ after the installation of the infiltration gallery.

\section{Discussion}

\section{General potability of filtered water}

The mean concentrations of the treated water quality are compared in Table 1 with acceptable limits by the World Health Organization (WHO, 1993). The data in Table 1 indicate that most of the water quality parameters of the filtered water are within the WHO (1993) guideline limits except for total iron. There was a general increase in ionic content from the raw water to the filtered water state. The general increase in total ionic and $\mathrm{pH}$ originates from the use of portland cement for the construction work. Chemical compounds present in portland cement include $3 \mathrm{CaHCO}_{3}, 2 \mathrm{CaSiO}_{2}, 3 \mathrm{CaOAl}_{3}$ and $\mathrm{Fe}_{2} \mathrm{O}_{3}$ (Mulkhlyonov, 1979). The effect of cement on the water quality as reported by FWR (1988) indicates that ordinary portland cement used as mortar lining gives rise to elevated $\mathrm{pH}$ in distribution mains due to lime leaching for several years in low alkalinity
TABLE 2

Geometric means and ranges of total and faecal coliform counts in Goviefe infiltration gallery

\begin{tabular}{|l|c|c|}
\hline & $\begin{array}{c}\text { Total } \\
\text { coliform counts } \\
(\mathbf{0}-\mathbf{1 0} / \mathbf{1 0 0} \mathbf{~} \boldsymbol{\ell})^{*}\end{array}$ & $\begin{array}{c}\text { Faecal } \\
\text { coliform counts } \\
(\mathbf{0} / 100 \mathbf{m} \boldsymbol{l})^{*}\end{array}$ \\
\hline $\begin{array}{l}\text { Raw water(n=9) } \\
\text { Filtered water(n=9) }\end{array}$ & $\begin{array}{c}\mathbf{3 8 8}(180-4600) \\
\mathbf{2 4}(6-80)\end{array}$ & $\begin{array}{c}\mathbf{3 5}(5-530) \\
\mathbf{3}(0-8)\end{array}$ \\
\hline \multicolumn{2}{|c|}{ * Maximum permissible count imposed by WHO (1993) } \\
\hline
\end{tabular}

waters (around $35 \mathrm{mg} / \ell \mathrm{CaCO}_{3}$ ). There is no effect of portland cement when alkalinity levels are greater than $55 \mathrm{mg} / \ell \mathrm{CaCO}_{3}$. The raw water pond had alkalinities ranging between 30 and $88 \mathrm{mg} / \ell$ $\mathrm{CaCO}_{3}$. This probably explains the elevation of $\mathrm{pH}$, alkalinity and hardness in the final filtered water due to lime leaching. Excessive iron in water supplies causes a metallic taste and stains household utensils and clothing. The source of iron in the filtered water (mean $=4.18 \mathrm{mg} / \ell$ ) probably emanates from the corroding pump parts, a phenomenon which was observed on site as the project progressed. Low $\mathrm{pH}$ water is known to cause corrosion in ungalvanised pump parts. Other sources of iron may have been leaching from the cement that contains $\mathrm{Fe}_{2} \mathrm{O}_{3}$ used in the construction work.

\section{Bacteriological potability}

The pond water is largely polluted with faecal matter (range: 5 to $530 \mathrm{cfu} / 100 \mathrm{~m} \ell$ ). For untreated unchlorinated water supplies, detection of faecal coliforms alone can generally serve as an adequate guide for determining whether pathogenic organisms are present in the water. Possible sources of contamination of the pond include: faecal matter in runoff and overland flows in the catchment of the pond, bird droppings and human contact. There was a reduction in faecal coliforms after treatment (range 0 to $8 \mathrm{cfu} / \ell$ ) as no faecal coliforms were detected in most of the samples. This is an indication that the infiltration gallery shows acceptable performance.

\section{Conclusion and recommendations}

The installed infiltration gallery is achieving acceptable performance as most of the physico-chemical parameters meet the criteria for drinking water by WHO (1993). The iron levels in the filtered water are, however, high and may require further treatment. The bacteriological quality is acceptable. To further improve the water supply it may be necessary for the community to do the following:

- Avoid farming activities and human contact around the pond.

- Prevent unauthorized entry into the pond by fencing.

- Institute frequent monitoring of the system.

- Install a simple iron removal plant to reduce iron to acceptable levels.

- Use brass, stainless steel or uPVC components in pipes and pumps.

\section{References}

ANDANI SM (1996) Community Water Supply in Volta Region. Proc. $22^{\text {nd }}$ WEDC Conf., New Delhi. India. 
ASARE EB (1996) Field Testing of an Infiltration Gallery at GoviefeAgodome. WRRI Technical Report. Accra, Ghana.

FWR (1988) Cementitious Linings and Water Quality. Part 1: The Change in Conveyed Water Quality after Lining Water Mains with Ordinary Portland Cement. Report No: DWI0785. Foundation for Water Research.

MULKHLYONOV IP (1979) Chemical Technology 2. MIR Publishers, Moscow.
STANDARD METHODS (1998) Standard Methods for the Examination of Water and Wastewater (16 $6^{\text {th }}$ edn.). American Public Health Association (APHA), Washington DC.

WHO (1987) Guidelines for Drinking Water Quality. World Health Organisation, Geneva. Switzerland.

WHO (1993) Guidelines for Drinking Water Quality. World Health Organisation, Geneva. Switzerland. 